\title{
Dietary Protein Deficiency in Early Life of F1 and F2 Generations of Sprague Dawley Rats Disrupts the Reproductive Function
}

Nosarieme Omoregie Abey ( $\nabla$ nosariemeabey@gmail.com )

University of Lagos College of Medicine

Osaretin Albert Taiwo Ebuehi

University of Lagos College of Medicine

Ngozi Awa Imaga

University of Lagos College of Medicine

\section{Research}

Keywords: Protein deficiency, cycle irregularity, reproductive hormone, follicle, ovarian-degeneration.

Ovarian function, fertility index

Posted Date: March 12th, 2021

DOl: https://doi.org/10.21203/rs.3.rs-282354/v1

License: (a) (1) This work is licensed under a Creative Commons Attribution 4.0 International License.

Read Full License 


\section{Abstract}

Background: The ability to reproduce efficiently is an important characteristic that has evolved through natural selection. Nutrition can modulate reproductive activities at different levels, its effect on nutrition is therefore complex and less predictable. This study aims at investigating the underlying effect of persistent dietary protein deficiency during early life on reproductive parameters of subsequent $\left(\mathrm{F}_{1}\right.$ and $F_{2}$ ) generations.

Method: Rats in group of four (4) were fed daily, with different ration of protein diet (PD) formulated as: $21 \%$ protein diet, $10 \%$ protein diet, $5 \%$ protein diet and control diet (rat chow, containing $16-18 \%$ protein). They were fed ad libitum before mating, throughout gestation and lactation, and next generations were weaned to the maternal diet. Reproductive function analysis (which include; gestation and pubertal hormonal profiling, onset of puberty, oestrus cyclicity, sexual response) and morphometric analysis of the ovarian structure were carried out to assess associated consequences.

Results: showed significant reduction in the fertility index as a consequence of altered reproductive function in the protein deficient models at $P \leq 0.05$. Low protein diet posed suboptimal intrauterine condition, which was linked to increased prenatal morbidity and mortality, lowered birthweight delayed onset of puberty, induced cycle irregularity, altered follicular maturation and endocrine dysfunction in the protein deficient groups. Reproductive status of an individual female organism critically depends on the maintenance of ovarian structure and function that has been associated with the hypothalamic pituitarygonadal axis, hormonal events and sexual maturity.

Conclusion: There is therefore an association between persistent early life protein deficiency and reproductive response which mechanistically involves life-long changes in key ovarian cytoarchitecture and function.

\section{Introduction}

Reproductive health encompasses the reproductive processes, functions and system at all stages of life. It is an important component of general health (WHO, 2008). Nutrients when detected by the cellular sensor systems as dietary signals can influence certain phenotypic changes which may alter activities and homeostatic control process (Elizondo et al., 2019). Maternal malnutrition during gestation and lactation impairs embryonic fetal development which results in deleterious outcomes and imprints. With the growing human population, approximately one billion people suffer from protein deficiency one-third of which are stunted under five, because the global food system is currently failing to meet its nutritional needs (Wu et al., 2014)

Undernutrition occurs in adolescent pregnancy because of the competition that exists between fetus and mother for nutrients (Vega et al., 2016; Micheal and Sandel., 2003). Early-life exposures trigger processes that sets individual ready for particular circumstances that are anticipated in the postnatal and adulthood environment(Chan et al., 2015). Protein undernutrition can cause stunted growth, anemia, physical 
weakness, and edema (Abey et al., 2019). The ability to reproduce is central to the life history of all sexually reproducing organisms. The primordial follicle pool is built up at the early stage of development, and is therefore vulnerable to exposures at this stage of development. Therefore, reproductive maturation and capabilities depends on early-life events, (Chan et al; 2015). Previous reports from clinical and experimental studies have indicated that early-life problem is associated with a decline in ovarian follicular reserve, changes in ovulation rates, and altered age at onset of puberty. However, mechanisms underlying the regulation of the relationship between the early-life developmental environment and postnatal reproductive function are not clear (Somchit et al;2007).

Nutrition has pivotal effects on reproduction as it can modulate reproductive activity at multiple levels (Vega et al., 2017). The success of reproduction in all animals depends on the function of the hypothalamus-pituitary-gonad axis. The interaction between nutrition and reproduction has been established to have important implications for the reproductive performance of ewes (SomchitAssavacheep, 2011). Also, Nutritional status of individuals influences virtually all aspects of female reproductive performance starting at the fertilization to their oocytes and embryo quality (Silvestris et al., 2019). More than $10 \%$ of the world's population are affected by infertility (Rouchou, 2013). In developing countries, there are severe social, psychological and economic consequences for infertile men and women, especially in the low-resource settings where it may be associated with a significant risk of further impoverishing the health reserves and sustenance in the community, threatening survival and worsening poverty (Gerrits et al., 2012). This present work was undertaken with the aim to investigate the perinatal dietary protein deficiency effects on reproductive health of two (2) different generation $\left(F_{1}\right.$ and $\mathrm{F}_{2}$ - generations) of rat model. As such, the pubertal attainment, estrus cycle, fertility response, hormone profile and morphology of the ovary were used to validate this, the established consequence can inform some therapeutic interventions in cases of reproductive health issues resulting from persistent perinatal dietary deficiency.

\section{Materials And Methods}

Ethical Statement: The research was carried out following the guidelines of the Act 2004 health research standards for care and use of laboratory animal models. The College of Medicine University of Lagos Health Research Ethics Committee (local HREC; REC 11), gave approval to the protocol to carry out the research (CMUL/HREC/11/18/462).

\section{Animal Grouping/Maintenance}

Averagely 6-8 weeks old virgin female Wistar rats $(n=40)$ were obtained from the animal house of the College of Medicine University of Lagos, Lagos Nigeria. Rats were grouped into four (4) according to the ration of protein in the diets; All rats were maintained in clean capacious plastic cages ( $n=10$ per cage) under standard laboratory conditions which include; neat environment, good aeration and lighting, with suitable $\left(25^{\circ} \mathrm{C} \pm 2^{0} \mathrm{C}\right)$ at a 12 -hour light/dark cycle and feeding ad libitum. 
Diet Formulation: Non-purified isocaloric diet was formulated. The diet was formulated using non-purified constituents and standard formula, scored to requirements following adaptation from New Non-purified Diet (NTP-2000) for Rodents by Ghanto Rao, 1997. The various protein ration diet for rat was formulated by scoring the proximate protein content to percentage in each dietary component and confirming the overall proximate analysis. Contents include: Maize, Fish meal, Soybean meal, cassava, wheat offal, Bone meal, Oyster shell, premix, methionine, lysine, Common salt in varying percentage towards the attainment of the experimental diet protein percentage for each grouping, in the modified method of Silas et al., (2014). Feed were fed to animals in pelletized form.

Time-Mating: Rats were maintained on group diet for about 6 weeks before mating. Three (3) weeks prebreed, at proestrus/estrus phase, rats in each group were time-mated with certified reproductive male, following three (3) weeks pre-breed vaginal cytology, to establish cycle pattern. The presence of sperm plugs and/ spermatozoa in the vagina smear was used to confirm day 0 of conception. the confirmed pregnant dams were separated to produce $F_{1}$ generation, this process was repeated for $F_{1}$ generation to produce $F_{2}$ generation while the different diet group feeding continues. Pregnant rats were weighed every other day, underwent vaginal delivery and pups' weight was also taken at birth. Weaning was done at postnatal day 28 and anogenital distance (AGD) was used to determine and separate sex $(\leq$ or $\geq 2.5 \mathrm{~mm}$ as the reference value (Zambrano et al., 2006).

\section{Day 6 and 19 hormonal Assay:}

The pregnancy hormone was monitored. Maternal blood at 6 th and 19th day of gestation between $9^{\text {th }}$ and $10^{\text {th }}$ hour of the day, was collected, cold centrifuged at 3500 rpm, and prepared for ELISA assay. serum estradiol and progesterone levels were measured by ELISA following manufacturer's instructions on kit. This was also repeated for the $F_{1}$ generation.

\section{Implantation Study}

At gestation day 4 (GD5), dams were injected at the tail, with Evans blue dye (1 mg/ml) and allowed to circulate for about $15 \mathrm{~min}$, before sacrificing through cervical dislocation and the implantation sites (identified as distinct blue bands along the uterine horn) were observed, counted and recorded (Oludare and Iranloye, 2016).

\section{Pregnancy Outcome}

Birth weight, Fetal appearance and average fetal outcome and survival rate in each treatment group were taken.

\section{Fertility Index}

Fertility response and fertility index calculations were done following slightly modified procedures. Fertility Index $(\mathrm{FI})=$ (Number of models mated- Number of model pregnant) *100 (Watcho et al., 2009). 


\section{Onset of Puberty}

Caliper was used to take the anogenital distance (AGD) for determination of sex; using $\leq$ or $\geq 2.5 \mathrm{~mm}$ as the reference value (Zambrano et al., 2006). Male and female progeny were separated and the female were maintained ad libitum on the formulated diet until puberty. Onset of Puberty defined as the age of vaginal opening (Goldman et al., 2007), was assessed by visual inspection every other day. Opening was established as the complete separation of the membrane sheath covering the vaginal orifice.

\section{Oestrus Cycling}

Oestrus cycle monitoring follows vaginal opening. vaginal smears were collected using lavage technique to index the stage of the estrous. To establish the timing of the oestrus. cyclicity was recorded based on the proportion of leucocytes, epithelial cells and cornified cells, in the smear. Cycle was counted on intervals between proestrus and the next proestrus, and average duration is calculated in each treatment groups. (Marcondes et al., 2002). The cycle regularity was evaluated on; cycle length, percentage time spent in each cycle phase. Longer cycle length, more than $50 \%$ time in one stage is considered irregular cycle. Prolonged diestrus also indicated acyclic period or pseudopregnancy (Li et al., 2017).

\section{Pubertal Hormone:}

$\mathrm{F}_{1}$-generation serum estradiol and progesterone, Follicle Stimulating Hormone, Luteinizing Hormone, Testosterone and cortisol levels were measured at puberty (specifically the Estrus phase) by EIA kit (Monobind Inc. Lake forest USA), using hormone standards and the specific antibodies following manufacturer's instructions of kit.

\section{Morphometric analysis}

Both ovaries were removed for morphological study at diestrus phase. Tissue samples were fixed in formalin $(10 \%)$ solution for $14-16$ hours, at $4^{0} \mathrm{C}$, the samples were dehydrated with alcohol solutions with increasing volume; followed by paraffin embedding. The samples were cut with a microtome $5 \mu \mathrm{m}$ diameter and consecutive staining with hematoxylin and eosin, sections were placed on slides (Ahmadi et al., 2017). In the final stage, ovarian morphology was assessed; the tissue sections taken from the ovaries were observed under light microscope with a magnification of 40 and the number of each of the follicular groups were counted, the thickness of theca layer and granulosa were then measured (Roshangar et al., 2014).

Statistical Analysis: Data were analyzed using diets as factors. Results are presented as the mean \pm SEM. Statistical analysis was performed using GraphPad Prism 7.0 for analysis of variance (ANOVA) followed by posthoc Turkey's test and/or Dunnette's test, at $P \leq 0.05$, statistical difference is considered significant.

\section{Results}




\begin{tabular}{ccccc} 
SAMPLE ID & PPD & NPD & MPD & CONTROL \\
\hline Moisture (\%) & $6.97 \pm 0.22$ & $7.43 \pm 0.02$ & $8.21 \pm 0.04$ & $8.51 \pm 0.44$ \\
\hline Crude Protein (\%) & $21.61 \pm 0.14$ & $5.76 \pm 0.12$ & $10.66 \pm 0.02$ & $15.98 \pm 0.05$ \\
\hline Crude Fat (\%) & $9.59 \pm 0.70$ & $13.76 \pm 0.07$ & $11.97 \pm 0.12$ & $10.16 \pm 0.03$ \\
\hline Crude Fiber (\%) & $1.56 \pm 0.04$ & $1.46 \pm 0.01$ & $1.60 \pm 0.21$ & $11.58 \pm 0.73$ \\
\hline Total Ash \% & $7.99 \pm 1.58$ & $6.49 \pm 0.02$ & $7.86 \pm 0.92$ & $7.31 \pm 0.09$ \\
\hline Carbohydate (NFE) \% & $52.28 \pm 1.13$ & $65.10 \pm 2.8$ & $59.93 \pm 1.11$ & $46.46 \pm 0.05$ \\
\hline Energy Value (MJ/Kg) & $14.916 \pm 2.11$ & $15.89 \pm 1.71$ & $16.736 \pm 1.12$ & $14.38 \pm 2.51$
\end{tabular}

PPD: $21 \%$ Protein Diet

NPD: 5\% Protein Diet

MPD: $10 \%$ Protein Diet

NFE: Nitrogen Free Extract (Carbohydrate CHO)

\section{Pregnancy/Pregnancy Outcomes}

Figure 2 shows the significant reduction in the gestation weight of the protein deficient pregnant dam at $F_{0}$ and $F_{1}$ generation. In Fig 3, circulating level of progesterone and estradiol at gestation day 6 and 19 in the $5 \% \mathrm{PD}$ and $10 \% \mathrm{PD}$ (deficient groups) were not significantly different from the $21 \%$ Protein diet and control group. There were significantly distinct features in protein deficient groups for the fertility index (Fig 4). Fetal resorption rate, Pups birthweight, and average fetal outcome at $F_{1} \& F_{2}$-generations (Table 2) were statistically different compared to control diet, while the gestation length (Table 2), did not change across the groups.

\section{Reproductive Function}

The onset of puberty measured as date of vaginal opening (Fig 5) in control and 21\%PD groups were within the normal range (PND 32), while the protein deficient groups (10\%PD and 5\%PD) had a late date of pubertal onset (PND 40 and 44 respectively). The pattern of oestrus cycle was disrupted in the nutritionally challenged groups (Fig 6a). Within four (4) weeks of vaginal cytology, Cycle irregularity was displayed for each of the protein deficient groups as the percentage of time spent in each oestrus phase (Fig 6a), was of higher variance compared to control's time spent in each cycle phase (Fig 6a) and cycle length (Fig 6b). Irregular cycle is taken as more than $50 \%$ time spent in diestrus stage or cycle length above 7 days. The $10 \% P D$ group in $F_{1}$ had persistent estrus phase (i.e vaginal cornification), while the $F_{1}$ and $\mathrm{F}_{2} 5 \% \mathrm{PD}$ displayed prolonged diestrus compared to other groups.

\section{Hormone at Puberty}

Fig $7 \& 8$ shows the pubertal hormone in all the groups, the protein deficient groups had significantly decreased level of follicle stimulating hormone, Progesterone (Fig 7), cortisol and testosterone (Fig 8), which are essential for the maturation of the ovarian structure. Although there was variation in the 
estradiol levels across the group but this was not significant. The Luteinizing hormone remained the same across the groups, in first and second generation.

Table 2: Pregnancy outcomes in $F_{0}$ And $F_{1}$ generations of the different diet groups.

\begin{tabular}{|c|c|c|c|c|c|c|c|c|}
\hline Generations & $\mathrm{F}_{0}$ & & & & $\mathrm{~F}_{1}$ & & & \\
\hline Groups & Control & $21 \% \mathrm{PD}$ & $10 \% \mathrm{PD}$ & $5 \% \mathrm{PD}$ & Control & $21 \% \mathrm{PD}$ & $10 \% \mathrm{PD}$ & $5 \% \mathrm{PD}$ \\
\hline $\begin{array}{l}\text { Fetal } \\
\text { Outcome } \\
\text { (Litter size) }\end{array}$ & $\begin{array}{l}8.330 \pm \\
0.333\end{array}$ & $\begin{array}{l}9.000 \\
\pm \\
0.577\end{array}$ & $\begin{array}{l}5.667 \quad \pm \\
0.667 \mathrm{a} * \mathrm{~b} * *\end{array}$ & $\begin{array}{ll}5.33 & \pm \\
0.333 \mathrm{a}^{*} \mathrm{~b}^{* *} & \end{array}$ & $\begin{array}{l}7.000 \\
\pm \\
0.442\end{array}$ & $\begin{array}{l}7.250 \\
\pm \\
0.478\end{array}$ & $\begin{array}{l}3.667 \\
0.889 \mathrm{a}^{*} \mathrm{~b} *\end{array}$ & $\begin{array}{l}4.000 \\
0.00 \mathrm{a}^{*} \mathrm{~b}^{*}\end{array}$ \\
\hline $\begin{array}{l}\text { Implantation } \\
\text { Losses } \\
\text { (Fetal } \\
\text { resorption } \\
\text { rate }\end{array}$ & $\begin{array}{l}0.113 \pm \\
0.018\end{array}$ & $\begin{array}{l}0.033 \\
\pm \\
0.033\end{array}$ & $\begin{array}{l}0.274 \quad \pm \\
0.013 \mathrm{a} * \mathrm{~b} * *\end{array}$ & $\begin{array}{l}0.329 \pm \\
0.019 \mathrm{a}^{*} \mathrm{~b}^{* *}\end{array}$ & $\begin{array}{l}0.0075 \\
\pm \\
0.003\end{array}$ & $\begin{array}{l}0.000 \\
\pm 0.00\end{array}$ & $\begin{array}{l}0.320 \\
0.106 \mathrm{a} * \mathrm{~b} *\end{array}$ & $\begin{array}{l}0.320 \\
0.01 \mathrm{a}^{*} \mathrm{~b}^{*}\end{array}$ \\
\hline $\begin{array}{l}\text { Pups } \\
\text { Birthweight }\end{array}$ & $\begin{array}{l}5.292 \pm \\
0.1274\end{array}$ & $\begin{array}{l}5.476 \\
\pm \\
0.1313\end{array}$ & $\begin{array}{l}4.05 \quad \pm \\
0.2409 \mathrm{a}^{* * *} \mathrm{~b}^{* *}\end{array}$ & $\begin{array}{l}\$ 2.7 \quad \pm \\
0.2261 \mathrm{a}^{* * *} \mathrm{~b}^{* *} \mathrm{C}^{*}\end{array}$ & $\begin{array}{l}4.905 \\
\pm \\
0.1468\end{array}$ & $\begin{array}{l}5.063 \\
\pm \\
0.1402\end{array}$ & $\begin{array}{l}3.863 \quad \pm \\
0.2228 \mathrm{a}^{* * *} \mathrm{~b} * *\end{array}$ & $\begin{array}{l}\$ 2.5 \\
0.1578 \mathrm{a}^{* * *} \mathrm{~b}^{* *} \mathrm{c}^{*}\end{array}$ \\
\hline $\begin{array}{l}\text { Gestation } \\
\text { length (days) }\end{array}$ & $\begin{array}{l}23 \\
0.42\end{array}$ & $\begin{array}{l}22 \\
0.68\end{array}$ & $22.1 \pm 0.14$ & $22.14+0.56$ & $\begin{array}{l}21.62 \\
\pm 0.95\end{array}$ & $\begin{array}{l}22.16 \\
\pm 0.6\end{array}$ & $22.04 \pm 0.48$ & $21.6 \pm 0.11$ \\
\hline
\end{tabular}

Data are expressed as mean \pm SEM, Control (standard rat chow containing 16-18\% Protein), 21\%PD (Upgraded daily recommended intake), 5\% (Protein deficient diet), 10\% (Mild protein deficient diet).

a < significantly different from control group $>$

b < Significantly different from the $21 \%$ Protein Diet group

Asterisks indicate the level of significance $(* \mathrm{P}<0.05 ; * * \mathrm{P}<0.001)$, *** $\mathrm{P}<0.0001$

Post-implantation Loss $=$ (Number of implantation- No of Fetuses alive) / Number of Implantation

\$ IUGR Condition was set at: Pup Weight $<10$ th percentile $($ i.e $<4 \mathrm{~g}$ )

\section{Ovarian Morphology}

The quantification of follicle and corpora lutea shows that at $F_{1}$, all other follicles were the same except the primary follicles which was significantly lowered and the cystic follicle which was higher significantly (Fig 9a) in the protein deficient groups. At $\mathrm{F}_{2}$; protein deficiency altered the number of primordial follicle $(\uparrow)$, cystic follicle $(\uparrow)$ and corpora lutea $(\downarrow)$ especially in the severe deficient group (5\%PD), compared to control, significant at $P<0.05$. The severely deficient group had significantly higher follicular diameter and lower theca and granulosa thickness(Fig 9b).

\section{Discussion}

Perinatal exposure to a protein deficient diet and general mother/child malnutrition during critical period of development is known to lead to certain life-long psychopathological changes and increased susceptibility to dysfunction that underlies most origins of health defects and disease. This study is 
targeted at investigating the reproductive consequences of perinatal dietary protein deficiency in two (2) subsequent generations of rat models, providing associated mechanism. The organ-system in the reproductive setup, in an attempt to make up for the deficiency may have undergone certain physiological and metabolic shifts which may directly or indirectly impart the shift in the hypothalamic pituitarygonadal axis that controls an aspect of reproduction.

Models under nutritional inadequacy were observed to have grown at a very slow pace during gestation, thus corroborating a previous report by Calin et al., (2019), The fetuses are exposed to sub-optimum environment as a result of the competition that exist between the mother and the fetus for the available nutrient, and this may have resulted in the consequential imprints observed in later life. Maternal constraint alters the development of fetus within the uterine which was evident as IUGR conditioning in the severely deficient group (5\%PD), and this corresponds with the low birthweight at both $\mathrm{F}_{1}$ and $\mathrm{F}_{2^{-}}$ generations. The sub-optimal intrauterine condition that result from the nutritional stress explains the low birthweight as earlier stated by Zambrano et al., 2005a. The survival, growth and development depended critically on the nutritional status of the mother and extent of protein deficiency, this result therefore emphasize that maternal protein intake directly impart intrauterine growth and survival (Woodall et al., 1996) and could also be explained by fetal programming effects.

Fertility index is key to reproductive health, delayed conception and reduced fertility response are consequences of protein deficiency as reported in this study. Although dietary protein deficiency did not affect pregnancy hormone, litter size and gestation length, across the generations, it is thought that there was a metabolic adjustment to cater for the pregnancy condition, and this must have accounted for the maintenance of the pregnancy till birth, for those dams that could carry pregnancy to term, this also explains why mortality rate was higher in the deficient group. The high rate of fetal resorption and survival in the protein deficient group has been hypothesized to share common etiology and therefore can be linked to the influence of dietary insufficiency on the maintenance of a viable pregnancy (Lee et al., 2000).

Delayed onset of puberty corresponds with lowered birthweight. We observed that vaginal opening(Onset of puberty) in the protein deficient models did not occur within the normal age range earlier reported by Picut et al., (2015), The diversity and progression of puberty has been linked to lowered birthweight (Castellano et al., 2011), this provides the basis for the fact that perinatal protein malnutrition is capable of programming the offspring's sexual maturity(Vickers et al., 2001), since epigenetic factors clearly play a role in sexual development. Susman and Trickell (2010) earlier stated that delayed onset of puberty may be inconsequential but the long-lasting differences associated with it may be detrimental, our result shows that the delayed puberty aligns with reduced fertility index in adult, therefore better explaining fertility intricacies and pregnancy outcomes earlier reported in the $F_{1}$ generation. Monitoring of vaginal smear at adolescent at onset of puberty in female rat provided useful ancillary measure of the cycle pattern. The irregular pattern of cycle following protein deficiency which was characterized by increased cycle length, percentage time spent in diestrus phase and prolonged estrus (Li et al., 2017). Prolong diestrus (indicating acyclic period or pseudopregnancy (Ann et al., 2019)) is a common pattern of 
disordered fertility (Caldwell et al., 2014), this condition was prominent in 5\%PD groups at $\mathrm{F}_{1}$ and $\mathrm{F}_{2}-$ generations. The 10\%PD was labelled with persistent estrus (vaginal cornification) in the $F_{1}$-generation, this is also known as delayed ovulation or anovulation (Ann et al., 2019). Long term diestrus and estrus phase, as well as altered cycle length are common signatures of reproductive ageing (de Oliveira et al., 2018; Li et al., 2017) and has also been implicated in prenatal androgenization of polycystic ovarian syndrome (Sullivan et al., 2004). Perinatal protein deficiency according to earlier research findings (Abey et al., 2019) correlates with altered dopaminergic and serotoninergic system. This result may also suggest why there is altered intra-generation reproductive function, since serotonin is established to stimulate ovarian maturation while hype in dopamine slows it down.

Puberty attainment as well as ovulation relies on concerted and complex convolution of the hypothalamic pituitary-gonadal axis. Any interference with luteinizing hormone (LH) and follicle stimulating hormone (FSH) periodic surge at puberty will delay ovulation and puberty, resulting in increased cystic and antral follicles and decreased corpora lutea, as earlier reported by Picut et al., (2015). The pubertal sex hormone profiling at estrus phase in this study decline in the 10\%PD and 5\%PD FSH as well as the progesterone levels which are key to pubertal attainment. The endocrine dysfunction according to Leonhardt et al., (2003), may underlie the cycle irregularity and delayed onset of puberty as seen in the deficient groups. Cortisol is expected to peak around ovulation and decrease rapidly fairly at the beginning of luteal phase (Cerda-Molina et al., 2013), in response to circadian rhythm, a high concentration of cortisol is usually available for biological actions preovulation, to reduce the inflammatory-like reactions that occurs in connection with ovulation, while the rapid lowering during the luteal phase is important for implantations and maintenance of pregnancy (Fanson et al., 2015), rather in this study, cortisol level was lowered at this phase of oestrus, thereby underlining the anovulaion and acyclic period displayed. Disruptions in this hormonal modulation may contribute to reproductive failures and ovarian dysfunction as observed in the cycling pattern of the protein deficient.

The maintenance of reproductive status and overall health critically depends on proper functioning of the ovary, and ovarian function is a subject of normal development of ovarian follicles (Devine et al., 2012). In sexually matured rats, ovarian cortex is characterized with development of follicles at different stages. The subsequent transition of primordial follicles into primary follicles are critical processes in normal ovulation physiology. Abnormalities in primordial transition can cause pathological conditions such as ovarian failure (Kizele and Skinner, 2003). The ovarian morphometric analysis was presented with decreased primary follicles (at $F_{1}$ ), and increased number of primordial follicles (at $F_{2}$ ), decreased corpora lutea and increased cystic follicles (at both $F_{1}$ and $F_{2}$ - generation) in the protein deficient groups as compared to control and $21 \% \mathrm{PD}$, which appeared normal showing the presence of follicles at all stages of development including corpora lutea. The persistent increase in cystic follicle and decreased corpora lutea from one generation to another are signatures of polycystic ovarian syndrome (PCOS) as reported by Osuka et al., (2019).

The altered ovarian architecture may directly impart function and this may in part be responsible for some abnormalities in reproductive function and fertility response earlier discussed. Corpus luteum 
matures during oestrus cycle and then regress. A degenerating corpora luteum is characterized by increased amount of fibrous tissue and yellow-brown lipofuscin pigment (Ahmadi et al., 2017), and Corpus lutea cyst is one of the functional cysts known to affect ovarian function in female domestic animals, while follicular cysts regress spontaneously with time and are clinically unapparent. Another underlying mechanism for the variation in ovarian morphology could be alteration in the follicular atresia process in the ovary, this process regulates the size and number of follicles in the developing pool. Increase in follicular atresia can be observed following induced condition of stress (which may be nutritional stress), where it continues to cause decrease in corpora lutea and inflamed ovary (Chou and Chen, 2018).

\section{Conclusion}

Nutrition is an important factor affecting pubertal development. It can therefore be suggested from this study that intragenerational perinatal protein deficiency can consequentially program reproductive developmental process, presenting a sub-optimal reproductive response and function in subsequent generation adults, as a function of normal development of ovary, ovarian follicles, endocrine dysfunction, ovarian degeneration and morphological variation. These therefore underlies the reproductive responses and function in perinatal dietary protein deficient model from one generation to another.

\section{Declarations}

Ethical Approval: The research was carried out following the guidelines of the Act 2004 health research standards for care and use of laboratory animal models. The College of Medicine University of Lagos Health Research Ethics Committee (local HREC; REC 11), gave approval to the protocol to carry out the research (CMUL/HREC/11/18/462).

\section{Consent to participate: N/A}

Consent for publication: All authors consent to the publication of the article

Availability of data and materials: Data are made available at request

Competing interests: There is no conflict of interest in this research.

Funding: no funding was received to carry out the research.

Author's contribution: $\mathrm{NA}, \mathrm{OE}$, and $\mathrm{NI}$ designed the study. $\mathrm{OE}$ and $\mathrm{NI}$ constructively supervised and review the bench work, results and manuscript, while NA carried out the analyses, statistical analysis, the literature search, and wrote the first draft of the manuscript.

Acknowledgement: The authors expresses their gratitude to Dr Oludare and Mr Micah of the Department of Physiology, College of Medicine University of Lagos, for technical support during the course of the research. 
Author's contribution: NA, OE, and NI designed the study. OE and $\mathrm{NI}$ constructively supervised and review the bench work, results and manuscript, while NA carried out the analyses, statistical analysis, the literature search, and wrote the first draft of the manuscript.

Authors' information: Nosarieme Omoregie Abey: nosariemeabey@gmail.com

Osaretin Albert Taiwo Ebuehi: ebueh@yahoo.com. Ngozi Awa Imaga: noamaga@gmail. Department of Biochemistry, Faculty of Basic Medical Sciences, College of Medicine, University of Lagos, Nigeria.

Corresponding author's postal and email address: nosariemeabey@gmail.com

\section{References}




\section{1. "WHO: Reproductive health". Retrieved 2008-08-19.}

2. Abey N.O, Ebuehi O.A.T and Imaga N.O.A 2019 Neurodevelopment and Cognitive Impairment in Parents and Progeny of Perinatal Dietary Protein Deficiency Models. Front. Neurosci. 13:826. doi: 10.3389/fnins.2019.00826.

3. Ahmadi M, Rostamzadeh A, Fathi F, Mohammadi M, Rezaie MJ 2017. The effect of Melatonin on histological changes of ovary in induced polycystic ovary syndrome model in mice. Middle East Fertility Society Journal; 22: 255-259

4. Ann E. Egan, Laurel R. Seemiller, Amy E.B. Packard, Matia B. Solomon and Yvonne M. Ulrich-Lai. 2019 Palatable food reduces anxiety-like behaviors and HPA axis responses to stress in female rats in an estrous-cycle specific manner, Hormones and Behavior, 10.1016/j.yhbeh.2019.07.005, 115, (104557),.

5. Carlin, G., Chaumontet, C., Blachier, F., Barbillon, P., Darcel, N., Blais, A., ... Davila, A. M. 2019. Maternal High-Protein Diet during Pregnancy Modifies Rat Offspring Body Weight and Insulin Signalling but Not Macronutrient Preference in Adulthood. Nutrients, 11(1), 96.

doi:10.3390/nu11010096

6. Castellano Juan M., Bentsen Agnete H., Sánchez-Garrido Miguel A., Ruiz-Pino Francisco, Romero Magdalena, David Garcia-Galiano, Enrique Aguilar, Leonor Pinilla, Carlos Diéguez, Jens D. Mikkelsen, Manuel Tena-Sempere 2011, Early Metabolic Programming of Puberty Onset: Impact of Changes in Postnatal Feeding and Rearing Conditions on the Timing of Puberty and Development of the Hypothalamic Kisspeptin System, Endocrinology, Volume 152, Issue 9, Pages 3396-3408, https://doi.org/10.1210/en.2010-1415

7. Cerda-Molina, A. L., Hernández-López, L., de la O, C. E., Chavira-Ramírez, R., \& Mondragón-Ceballos, R. 2013. Changes in Men's Salivary Testosterone and Cortisol Levels, and in Sexual Desire after Smelling Female Axillary and Vulvar Scents. Frontiers in endocrinology, 4, 159.

doi:10.3389/fendo.2013.00159

8. Chan KA, Tsoulis MW \& Sloboda DM 2015. Early-life nutritional effects on the female reproductive system.J Endocrinol 224, R45-62.

9. Chou, C.-H., \& Chen, M.-J. 2018. The Effect of Steroid Hormones on Ovarian Follicle Development. Ovarian Cycle, 155-175. doi:10.1016/bs.vh.2018.01.013

10. de Oliveira Ferreira, R., Guimarães, A.T.B., Rocha, T.L. et al 2018. The potential reproductive toxicity of tannery effluent to the estrous cycle and ovarian follicular dynamics of female Swiss mice. Environ Sci Pollut Res 25, 36355-36367 doi:10.1007/s11356-018-3527-4

11. Devine Patrick J., Perreault Sally D., Luderer Ulrike, 2012 Roles of Reactive Oxygen Species and Antioxidants in Ovarian Toxicity, Biology of Reproduction, Volume 86, Issue 2, 1 February 2012, 27, 110, https://doi.org/10.1095/biolreprod.111.095224

12. Elizondo-Vega RJ, Recabal A and Oyarce K 2019 Nutrient Sensing by Hypothalamic Tanycytes. Front. Endocrinol. 10:244. doi: 10.3389/fendo.2019.00244.

13. Fanson KV, Parrott ML 2015 The value of eutherian-marsupial comparisons for understanding the function of glucocorticoids in female mammal reproduction. Horm Behav 76:41-47.

https://doi.org/10.1016/j.yhbeh.2015.05.012

14. Gerrits T Ombelet W van Balen F Vanderpoel 2012. Biomedical infertility care in poor resource countries: barriers, access and ethics . FVV Obgyn . S (eds.) Monograph :1 -90

15. Goldman Jerome M., Ashley S. Murr, and Ralph L. Cooper 2007, The Rodent Estrous Cycle: Characterization of Vaginal Cytology and Its Utility in Toxicological Studies, Birth Defects Res (Part B) 80:84-97. 
16. Kezele Phillip, Skinner Michael K., 2003 Regulation of Ovarian Primordial Follicle Assembly and Development by Estrogen and Progesterone: Endocrine Model of Follicle Assembly, Endocrinology, Volume 144, Issue 8, 1, Pages 3329-3337, https://doi.org/10.1210/en.2002-0131

17. Kim D, Oh C, Hwang Y, Jeong I, Ahn K, Chung H and Chang J 2012 Serum Bisphenol A Concentration in Postmenopausal Women with Osteoporosis, Journal of Bone Metabolism, 10.11005/jbm.2012.19.2.87, 19:2, (87),

18. Lee AH, Gray PB, Gallagher PJ. 2000 Sudden death and regional left ventricular fibrosis with fibromuscular dysplasia of small intramyocardial coronary arteries. Heart.;83:101-102. [PMC free article] [PubMed] [Google Scholar]

19. Li J, Kim JS, Abejuela VA, Lamano JB, Klein NJ, Christian CA 2017 Disrupted female estrous cyclicity in the intrahippocampal kainic acid mouse model of temporal lobe epilepsy. Epilepsia Open 2(1):39-47

20. Li J, Kim JS, Abejuela VA, Lamano JB, Klein NJ, Christian CA 2017 Disrupted female estrous cyclicity in the intrahippocampal kainic acid mouse model of temporal lobe epilepsy. Epilepsia Open 2:39-47. 10.1002/epi4.12026

21. Marcondes, f. K., bianchi, f. J. And tanno, a. P., 2002 determination of the estrous cycle phases of rats: some helpful considerations, Braz. J. Biol., 62(4A): 609-614.

22. Marion Léonhardt, Jean Lesage, Dominique Croix, Isabelle Dutriez-Casteloot, Jean C. Beauvillain, Jean P. Dupouy, 2003 Effects of Perinatal Maternal Food Restriction on Pituitary-Gonadal Axis and Plasma Leptin Level in Rat Pup at Birth and Weaning and on Timing of Puberty, Biology of Reproduction, Volume 68, Issue 2, Pages 390-400, https://doi.org/10.1095/biolreprod.102.003269

23. Oludare, G.O.; Iranloye, B.O. 2016 Implantation and pregnancy outcome of Sprague-Dawley rats fed with low and high salt diet. Middle East Fertil. Soc. J., 21, 228-235.

24. Osuka, S., Nakanishi, N., Murase, T., Nakamura, T., Goto, M., Iwase, A., \& Kikkawa, F. 2018. Animal models of polycystic ovary syndrome: A review of hormone-induced rodent models focused on hypothalamus-pituitary-ovary axis and neuropeptides. Reproductive medicine and biology, 18(2), 151-160. doi:10.1002/rmb2.12262

25. Picut, C. A., Dixon, D., Simons, M. L., Stump, D. G., Parker, G. A., \& Remick, A. K. 2015. Postnatal Ovary Development in the Rat: Morphologic Study and Correlation of Morphology to Neuroendocrine Parameters. Toxicologic Pathology, 43(3), 343-353. https://doi.org/10.1177/0192623314544380.

26. Roshangar, L., Hamdi, B. A., Khaki, A. A., Rad, J. S., \& Soleimani-Rad, S. 2014. Effect of lowfrequency electromagnetic field exposure on oocyte differentiation and follicular development. Advanced biomedical research, 3, 76. doi:10.4103/2277-9175.125874

27. Rouchou, B. 2013. Consequences of infertility in developing countries. Perspectives in Public Health, 133(3), 174-179. https://doi.org/10.1177/1757913912472415

28. Silas A. F., Ayorinde, A.O., Daisy, E., Mark, S.O., Bolanle, O.O. and Nwakaegh, E.G. 2014. Effect of stocking densityand quantitative feed restriction on growth performance, digestibility, haematological characteristics and cost of starting broiler chicks. J. Anim. Health \& Prod., 2: 60-64.

29. Silvestris E, Lovero D and Palmirotta R 2019 Nutrition and Female Fertility:An Interdependent Correlation. Front. Endocrinol. 10:346. doi: 10.3389/fendo.2019.00346

30. Sullivan SD, Moenter SM (2004), prenatal androgens alters GABAergic drive to gonadropin-releasing neurons; implications for common fertility disorder. Proc Natl Acad Sci U S A ; 101:7129-7134. 
31. Watcho P, Ngadjui E, Alango PNE, Benoit TN, Kamanyi A (2009). Reproductive Effects of Ficus asperifolia (Moraceae) in Female Rats. Afr. Health Sci. Vol. 9(1): 1-5.

32. Woodall, S., Johnston, B., Breier, B. et al 1996. Chronic Maternal Undernutrition in the Rat Leads to Delayed Postnatal Growth and Elevated Blood Pressure of Offspring. Pediatr Res40, 438-443 doi:10.1203/00006450-199609000-00012

33. Wu, G., Fanzo, J., Miller, D.D., Pingali, P., Post, M., Steiner, J.L. and Thalacker-Mercer, A.E. 2014, Production and supply of high-quality food protein for human consumption: sustainability, challenges, and innovations. Ann. N.Y. Acad. Sci., 1321: 1-19. doi:10.1111/nyas. 12500

34. Zambrano E, Martinez-Samayoa PM, Bautista CJ, Deas M, Guillen L, Rodriguez-Gonzalez GL,Guzman C, Larrea F, Nathanielsz PW 2005. Sex differences in transgenerational alterations of growth and metabolism in progeny (F2) of female offspring (F1) of rats fed a low protein diet during pregnancy and lactation. J Physiol566: 225-236.

35. Zambrano, E., Bautista, C. J., Deás, M., Martínez-Samayoa, P. M., González-Zamorano, M., Ledesma, H., ... Nathanielsz, P. W. 2006. A low maternal protein diet during pregnancy and lactation has sexand window of exposure-specific effects on offspring growth and food intake, glucose metabolism and serum leptin in the rat. The Journal of physiology, 571(Pt 1), 221-230. doi:10.1113/jphysiol.2005.100313

\section{Figures}




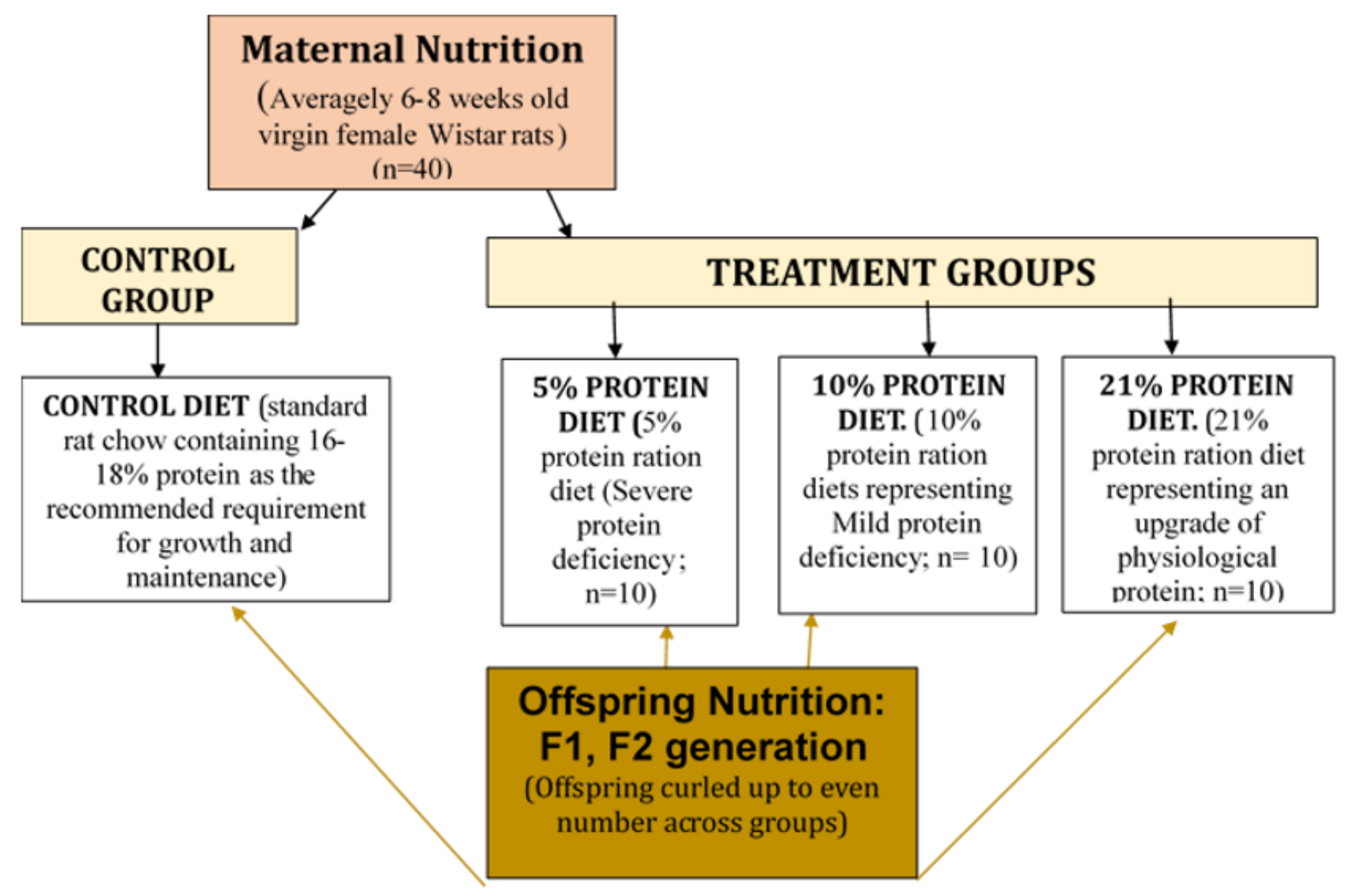

Figure 1

Schematic diagram of feeding pattern

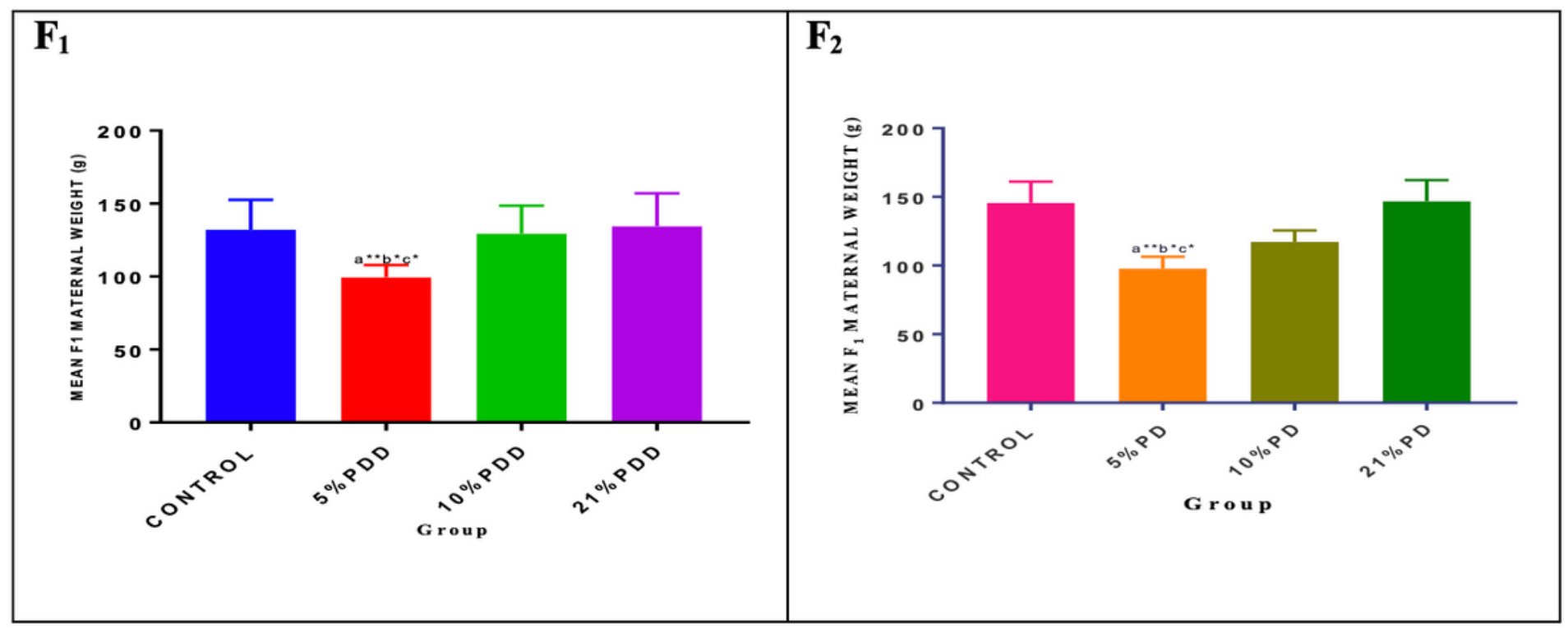

Figure 2 
Mean maternal weight in the different diet groups of F1 and F2-generations Data are expressed as mean \pm SEM, Control (standard rat chow containing 16-18\% Protein), 21\%PD (Upgraded daily recommended intake), $5 \%$ (Protein deficient diet), 10\% (Mild protein deficient diet). a < significantly different from $21 \%$ diet group and or control $>b<$ significantly different from the $10 \%$ diet group $>\left({ }^{*} P<0.05, * \star P<0.001, * \star * P<\right.$ $0.0001)$

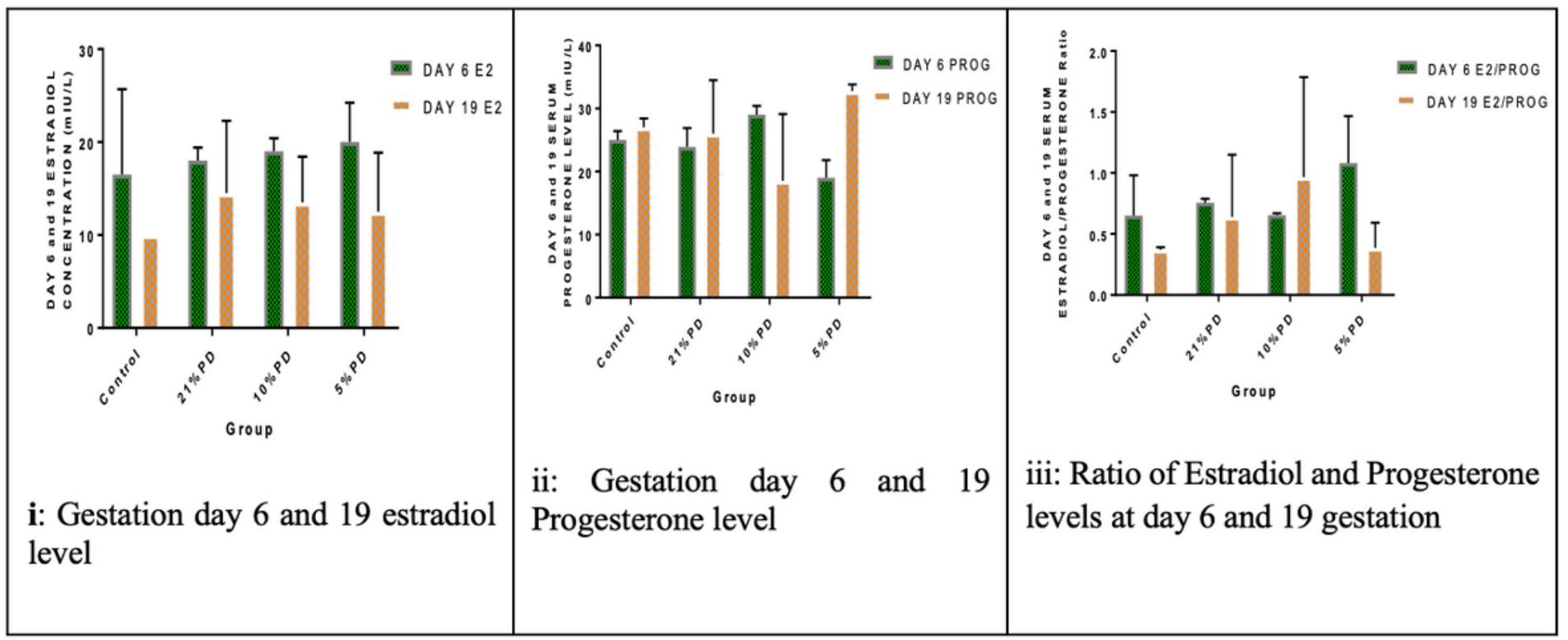

\section{Figure 3}

Mean Serum Estradiol and Progesterone levels on gestation day 6 and 19 in the different diet groups. F1 and F2-generations Data are expressed as mean \pm SEM, Control (standard rat chow containing 16-18\% Protein), 21\%PD (Upgraded daily recommended intake), 5\% (Protein deficient diet), 10\% (Mild protein deficient diet). There were no significant differences in the gestational level of plasma estrogen and progesterone at Gestation day 6 and 19. E2: Estradiol, PROG: Progesterone, PD: Protein Diet. a < significantly different from $21 \%$ diet group and or control $>$ b $<$ significantly different from the $10 \%$ diet group $>\left({ }^{*} P<0.05\right.$, ${ }^{\star \star} P<0.001$, $\left.{ }^{* \star *} P<0.0001\right)$ 


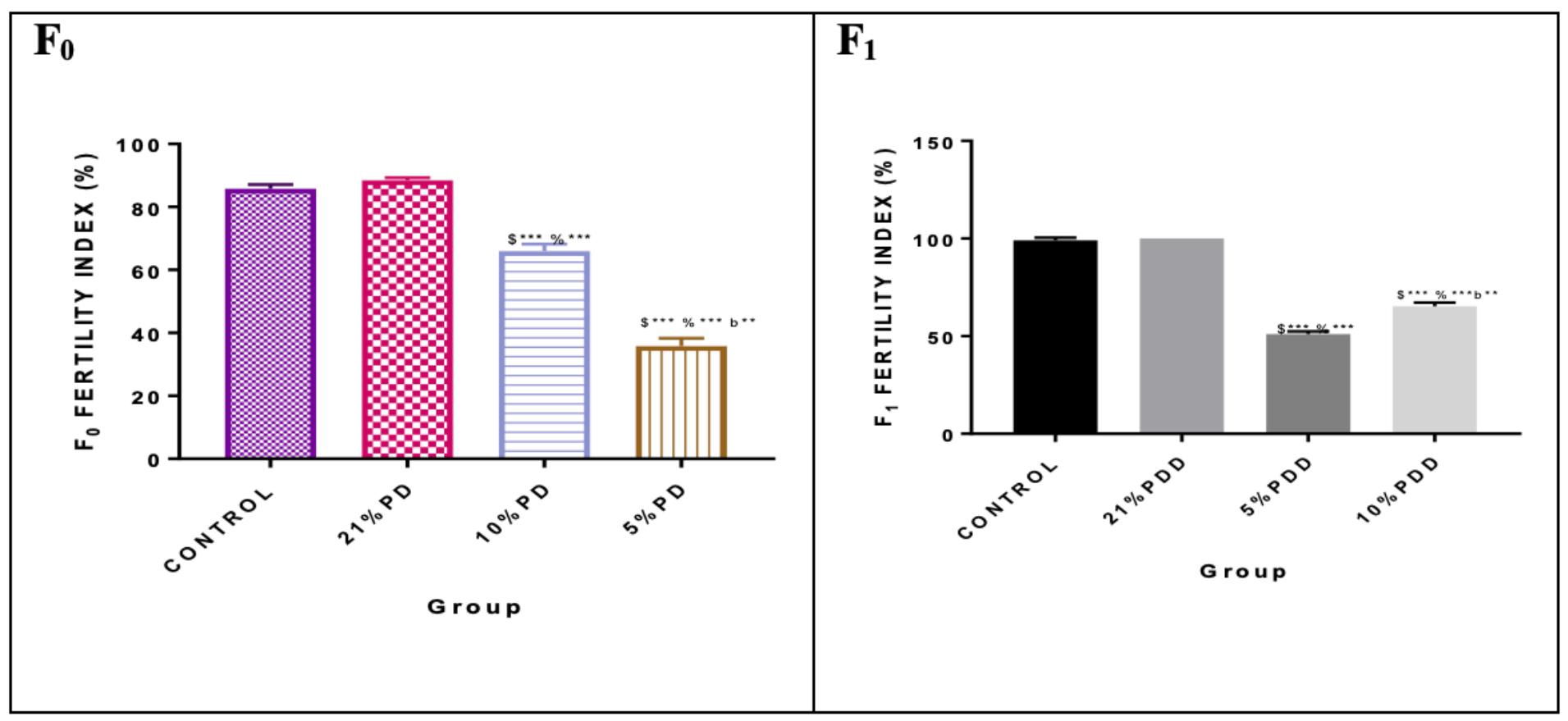

\section{Figure 4}

Mean F1 \& F2 generation Fertility Index in each of the different diet groups of rats. Data are expressed as mean \pm SEM, Control (standard rat chow containing 16-18\% Protein), 21\%PD (upgraded daily recommended intake), $5 \%$ (Protein deficient diet), 10\% (Mild protein deficient diet). a < significantly different from control group $>b$ : $<$ Significantly different from $21 \%$ Protein Diet group $>c<$ Significantly different from $10 \% \mathrm{PD}$ group ( ${ }^{*} \mathrm{P}<0.001$, $* \star * \mathrm{P}<0.0001$ )

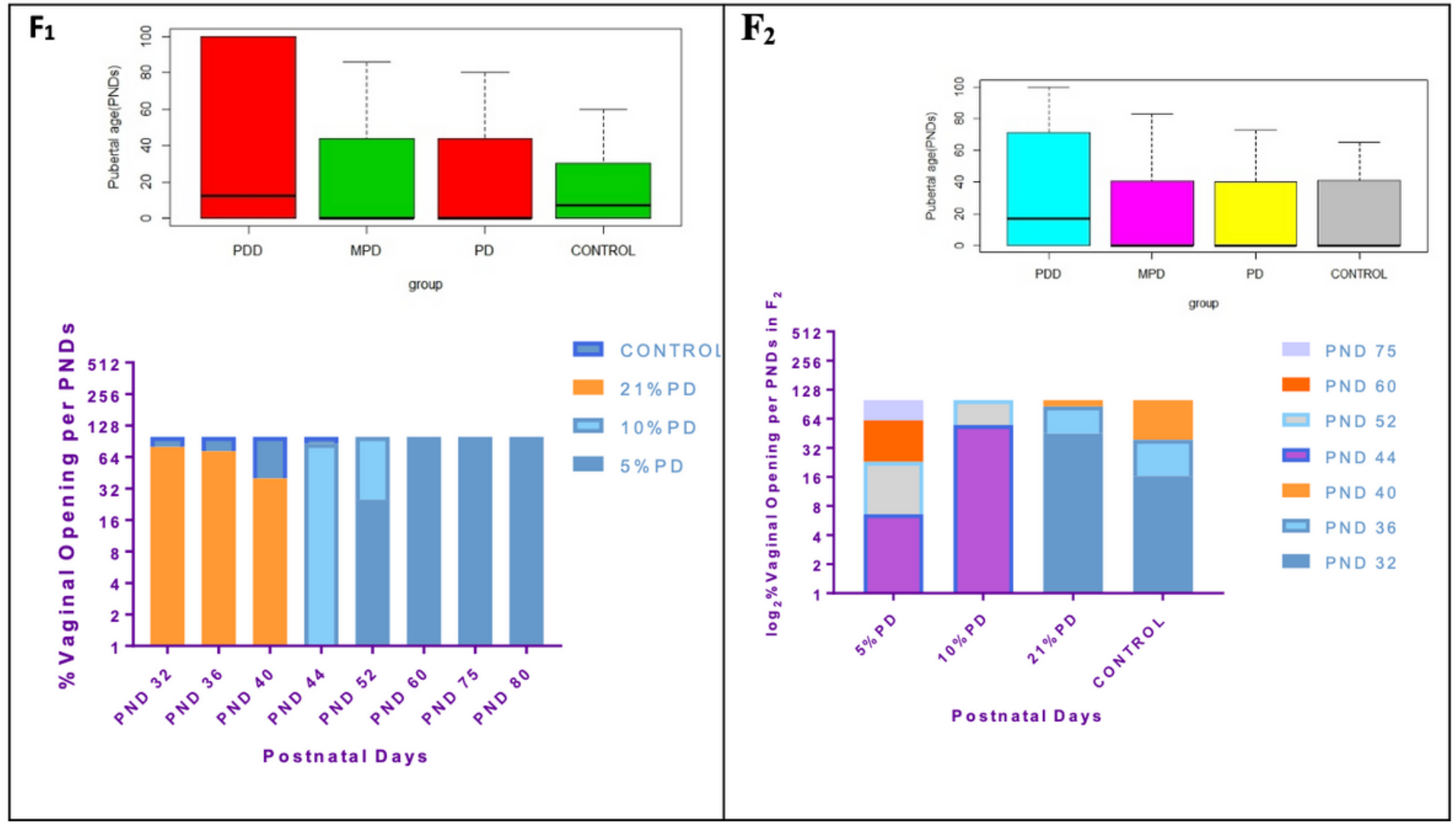




\section{Figure 5}

The Plot of percentage vaginal opening at different postnatal days (between PND $32-80$ ) in each of the diet groups, Data are expressed as mean \pm SEM, Control (standard rat chow containing $16-18 \%$ Protein), $21 \% \mathrm{PD}$ (upgraded daily recommended intake), 5\% (Protein deficient diet), 10\% (Mild protein deficient diet). Statistically significant difference between individual group and $5 \% \mathrm{PD}\left({ }^{*} \mathrm{P}<0.05\right)$ and the hypothetical value of 7day cycle length. A Persistent cycle length $>7$ days reflects an irregular cycle. PD: Protein Deficient Diet. PND: Postnatal Days Color areas represent portion of group with vaginal opening at that postnatal date. Box plot: shows average age of pubertal onset. (PPD: 21\% Protein Diet, NPD: 5\% Protein Diet, MPD: 10\% Protein Diet. 
A

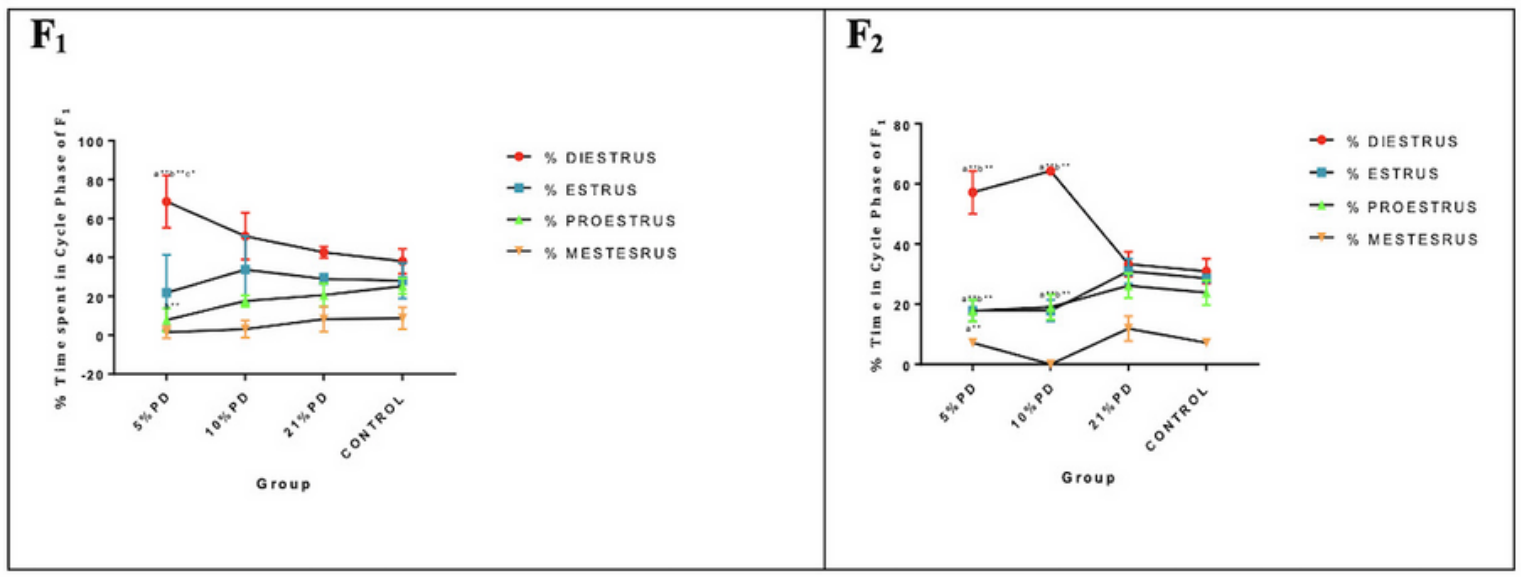

B

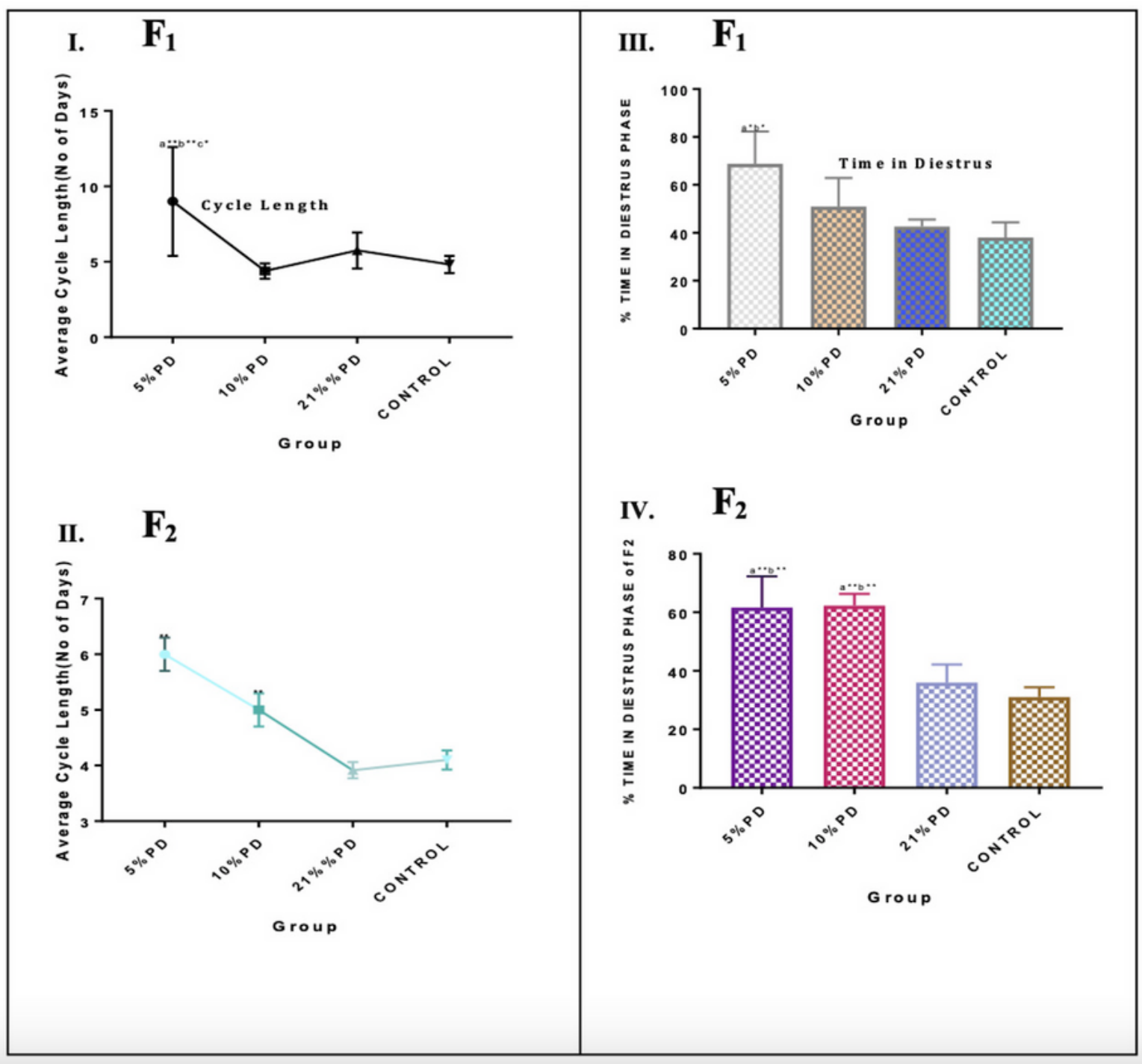

\section{Figure 6}

A: Oestrus Cyclicity in F1 and F2-generations presented as average Percentage time spent in each cycle phase by each of the diet groups, Data are expressed as mean \pm SEM, Control (standard rat chow containing 16-18\% Protein), 21\%PD (upgraded daily recommended intake), 5\% (Protein deficient diet), 10\% (Mild protein deficient diet). Statistically significant difference between individual group and 5\% PD $\left({ }^{\star} \mathrm{P}<0.05\right)$ and the hypothetical value of 7 day cycle length. A Persistent cycle length $>7$ days reflects an 
irregular cycle. PD: Protein Deficient Diet. a < significantly different from $21 \%$ diet group and or control > $b<$ significantly different from the $10 \%$ diet group $>\left({ }^{*} P<0.05,{ }^{*} P<0.001,{ }^{*} * \mathrm{P}<0.0001\right)$. B: Mean Cycle length of the estrus and the \% time spent in diestrus in F1 and F2-generations of each of the diet groups. Data are expressed as mean \pm SEM, Control (standard rat chow containing 16-18\% Protein), $21 \% \mathrm{PD}$ (upgraded daily recommended intake), 5\% (Protein deficient diet), 10\% (Mild protein deficient diet). a < significantly different from $21 \%$ diet group and or control $>$ b $<$ significantly different from the $10 \%$ diet group $>\left({ }^{*} P<0.05,{ }^{*} \mathrm{P}<0.001,{ }^{*} * \mathrm{P}<0.0001\right)$ I \& II; Average cycle length at F1 and F2 -generations III \& IV; Percentage Time in Diestrus phase.at F1 and F2 - generations.

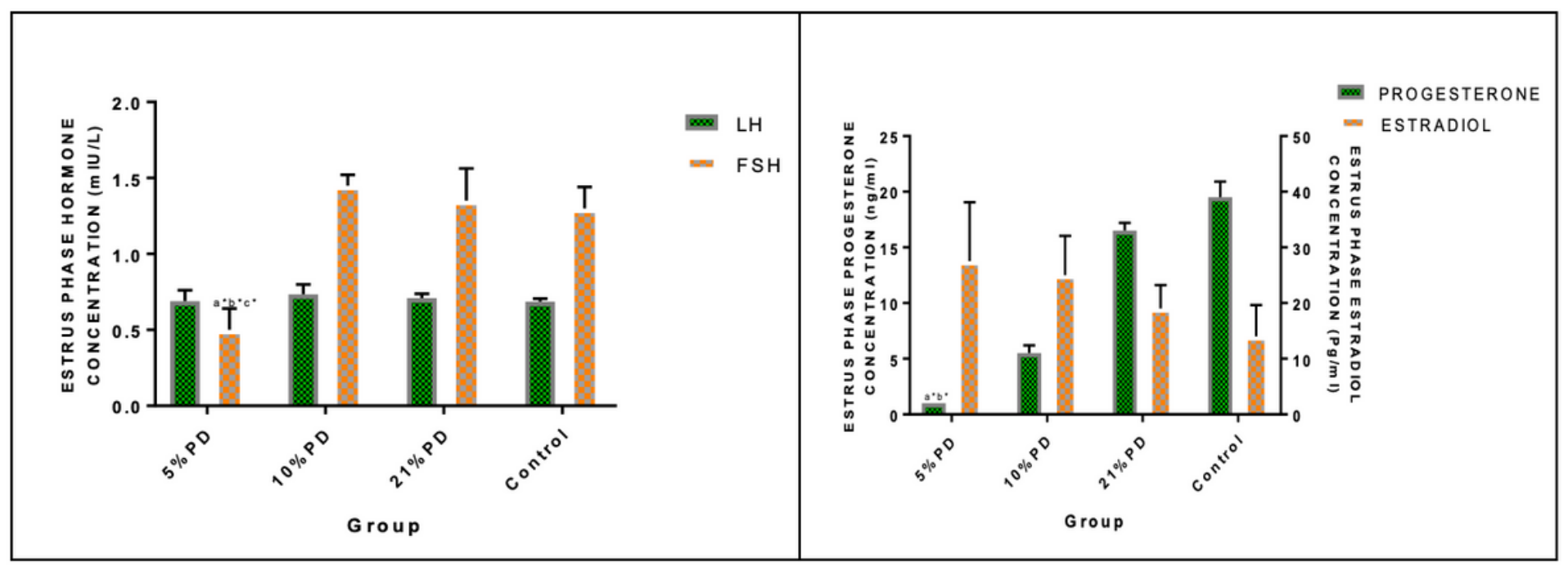

\section{Figure 7}

Mean Serum concentration of Luteinizing Hormone (LH), Follicle stimulating Hormone (FSH) Progesterone and Estradiol during Estrus Phase of the F1 generation in different diet groups. Data are expressed as mean \pm SEM, Control (standard rat chow containing 16-18\% Protein), 21\%PD (upgraded daily recommended intake), 5\% (Protein deficient diet), 10\% (Mild protein deficient diet). a < significantly different from $21 \%$ diet group and or control $>$ b $<$ significantly different from the $10 \%$ diet group $>\left({ }^{*} P<0.05\right.$, $\left.\star * \mathrm{P}<0.001,{ }^{* \star *} \mathrm{P}<0.0001\right)$

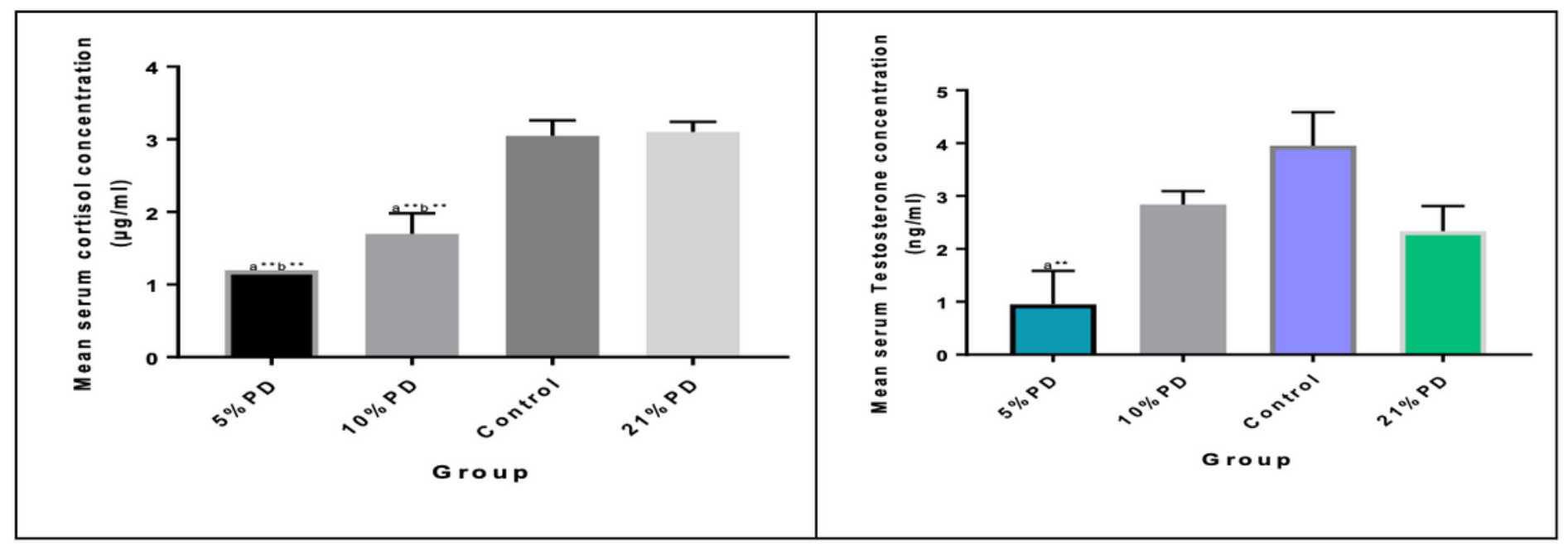




\section{Figure 8}

Concentrations of Cortisol and Testosterone $(\mu \mathrm{g} / \mathrm{g})$ in the F1 -generation in each of the different diet group of rats. Data are expressed as mean \pm SEM, Control (standard rat chow containing $16-18 \%$ Protein), $a<$ significantly different from $21 \%$ diet group and or control $>b<$ significantly different from the $10 \%$ diet group $>\left({ }^{*} \mathrm{P}<0.05,{ }^{*} \mathrm{P}<0.001,{ }^{* \star *} \mathrm{P}<0.0001\right)$.

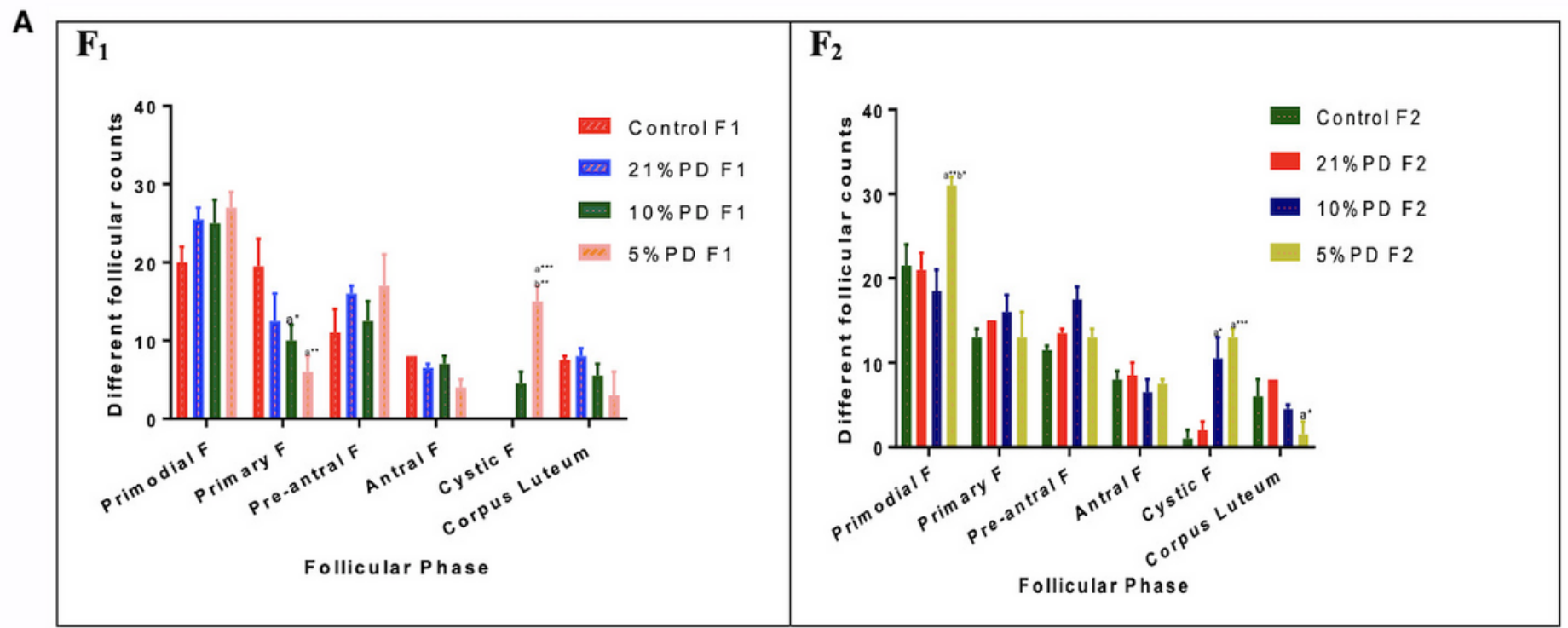

B

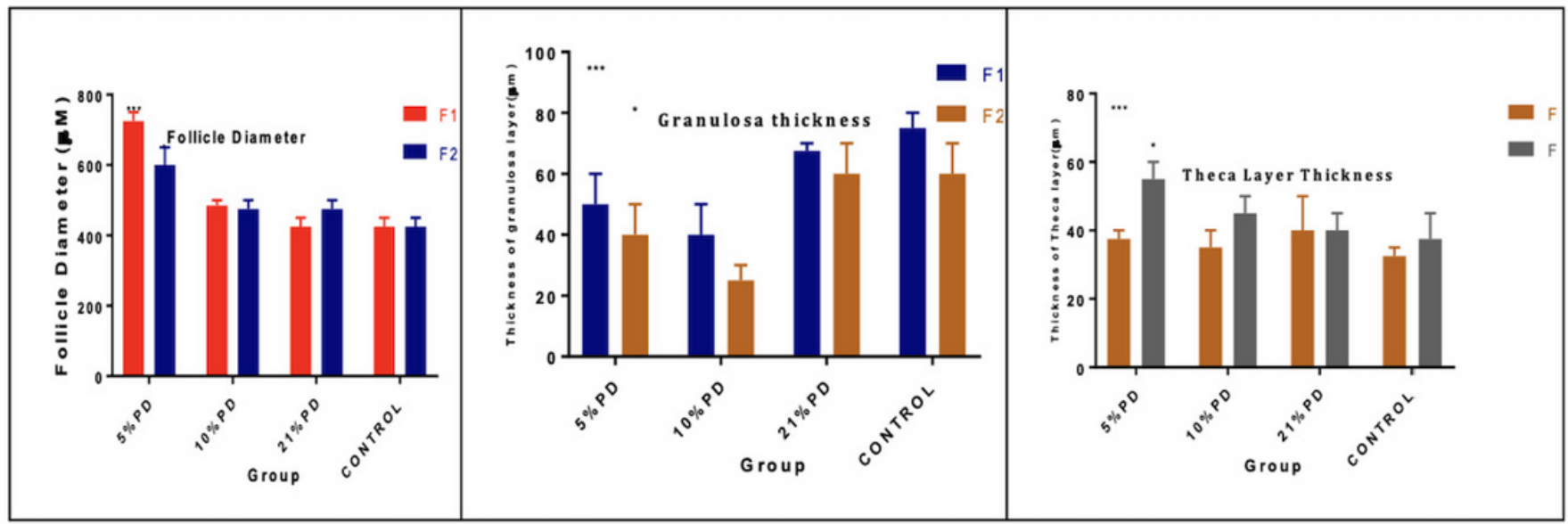

Figure 9

A: Comparison of index numbers of the Follicle numbers in different diet groups of the Female F1 and F2generations, in Ovarian Morphology changes Data are expressed as mean \pm SEM, Control (standard rat chow containing 16-18\% Protein), 21\%PD (upgraded daily recommended intake), 5\% (Protein deficient diet), 10\% (Mild protein deficient diet). a < significantly different from 21\% diet group and or control > $\mathrm{b}<$ significantly different from the $10 \%$ diet group $>\left({ }^{*} P<0.05\right.$, $\left.{ }^{*} P<0.001, * \star * P<0.0001\right)$ B: The morphometry of Follicle diameter, Granulosa layer and theca layer thickness in various diet groups' ovary Data are expressed as mean \pm SEM, Control (standard rat chow containing 16-18\% Protein), 21\%PD (upgraded daily recommended intake), 5\% (Protein deficient diet), 10\% (Mild protein deficient diet). *,**< 
significantly different from $21 \%$ diet group and or control $>* * *<$ significantly different from all other diet group $>(P<0.001)$. F1 and F2 are first and second generations respectively. 